\title{
Comparison of the Continuous and Intermittent Relaxation Test
}

Vladimir Sleger, Cestmir Mizera

Faculty of Engineering, Czech University of Life Sciences Prague. Kamycka 129, 16521 Praha 6 - Suchdol. Czech Republic. E-mail: sleger@tf.czu.cz,mizera@tf.czu.cz

The article presents the measurement results of the relaxation of long-term loaded compression springs manufactured out of non-alloy steel. The goal was to determine the differences between the interrupted and uninterrupted tests. During the relaxation test that lasted $5000 \mathrm{hr}$ in a laboratory with a temperature of $22^{\circ} \mathrm{C}$, initial shear stress set at a value of $30 \%$ of the ultimate tensile strength of the material, decreased the strength of the springs with a wire diameter of $1 \mathrm{~mm}$ by $3.6 \%$, springs with a wire diameter of $3.15 \mathrm{~mm}$ by $2.5 \%$, and springs with a wire diameter of $5 \mathrm{~mm}$ by $1.3 \%$. The difference in the results was found in tests 16 times and 4 times interrupted to measure the current relaxation. The results of intermittent tests cannot be considered as relaxation values for statically loaded springs. Conversely, when determining the maximum tension of quasi-statically loaded springs with respect to the relaxation, the uninterrupted relaxation tests cannot be used.

Keywords: Compression springs, Patented wire, Long-term test, Room temperature, Static loading

\section{Acknowledgement}

This paper was supported by the IGA, Project 2013:31130/1312/3105 (Mechanical properties of resilient elements of agricultural machines).

\section{References}

[1] BATANOV, M. V., PETROV, N. V. (1953). Ocelové pružiny, pp. 205 - 220. SNTL, Prague.

[2] CSN EN 10319-1 (2003). Metallic materials - Tensile stress relaxation testing - Part 1: Procedure for testing machines, pp. 11 - 12. Czech Standards Institute, Prague.

[3] CSN EN 13906-1 (2014). Cylindrical helical springs made from round wire and bar-Calculation and design-Part 1: Compression springs, pp. 15, 20, 29. The Office for Standards, Metrology and Testing, Prague.

[4] DEDA, S., ZHISHOU, Z., XINHUA, W. (1997). Research on Anti stress relaxational ability of helical compression springs made of austenitic stainless steel wires. In: Steel Wire Products, Vol. 1997, No. 2, pp. 14 - 22. ISSN 1003-4226.

[5] DYKHUIZEN, R. C., ROBINO, C. V. (2004). Load relaxation of helical extension springs in transient thermal environments. In: Journal of Materials Engineering and Performance, Vol. 13, No. 2, pp. 151 - 157. ISSN 10599495.

[6] GEINITZ, V., WEISS, M., KLETZIN, U., BEYER, P. (2011). Relaxation of helical springs and spring steel wires. In: Innovation in Mechanical Engineering - Shaping the Future (P. Scharff, P. Kurtz, (Ed.)). TU Ilmenau, Ilmenau.

[7] IDERMARK, S. U. V., JOHANSSON, E. R. (1979). Room-temperature stress relaxation of high-strength strip and wire spring steels - procedures and data. In: Stress Relaxation Testing (A. Fox, (Ed.)), pp. 61 - 77. American Society for Testing and Materials, Baltimore.

[8] KOPAS, P., SÁGA, M. (2013). In-phase multiaxial fatigue experimental analysis of welded cylindrical 6063-T66 aluminium alloy specimens. In: Manufacturing Technology, Vol. 13, No. 1, pp. 59 - 64. ISSN 1213-2489.

[9] POTHIER, N. E. (1976). Observed load deflection characteristics of Belleville springs under static loads at room and elevated temperatures, pp. 5 - 6. Atomic Energy of Canada, Chalk River.

[10]ROSENBERG, G., JUHÁR, L. (2012). Fatigue resistance of dual phase steels in presence of microstructural inhomogeneities. In: Manufacturing Technology, Vol. 12, No. 13, pp. 217 - 221. ISSN 1213-2489.

[11] SEGLA, Š., OREČNÝ, M., TRIŠOVIĆ, N. (2013). Semiactive seat suspension with a vibrator absorber. In: Manufacturing Technology, Vol. 13, No. 4, pp. 534 - 539. ISSN 1213-2489.

[12] SHIGLEY, J. E., MISCHKE, C. R., BUDYNAS, R. G. (2010). Konstruování strojních částí, pp. 563 - 564. VUTIUM, Brno. ISBN 978-80-214-2629-0.

[13] YU, Y. Z., ZHOU, X. Y. (2010). Experimental research on stress relaxation of diskspring used for laser optical mounts. In: Advanced Materials Research, Vol. 129 - 131, pp. 531 - 535. TTP. Switzerland. 